\title{
Determination of the Stress-Index After Long Walking and 4 Cups of Instant Coffee in Adult Man
}

\author{
Ivan Domuschiev* \\ Multiprofile Transport Hospital, Department of Internal Diseases, Bulgaria
}

*Corresponding author: Ivan Domuschiev, Multiprofile Transport Hospital, Department of Internal Diseases, Plovdiv City

(Bulgaria)

\begin{tabular}{|c|c|}
\hline ARTICLE INFO & ABSTRACT \\
\hline Received: 㓞 May 24, 2021 & $\begin{array}{l}\text { Citation: Ivan Domuschiev. Determination of the Stress-Index After Long Walking and } \\
4 \text { Cups of Instant Coffee in Adult Man. Biomed J Sci \& Tech Res 36(2)-2021. BJSTR. }\end{array}$ \\
\hline Published: 幽 June 04, 2021 & MS.ID.005824. \\
\hline
\end{tabular}

\section{Case Report}

It is known that coffee and its caffeine have an invigorating and stimulating effect on the human body. The mechanism of action is carried out by activating the sympathetic nervous system and increasing stress hormones. We measured the level of stress and other parameters of Pulse Rate Variability (PRV) in a 60-year-old man $[1,2]$.

He is $178 \mathrm{~cm}$ tall, weighs $75 \mathrm{~kg}$ and has a BMI of 24. In our case, we measured the Stress-Index and other parameters of Heart Rate Variability (HRV) for 1 minute 30 seconds using a chest belt with Heart Rate Monitor

"Kalenji" (with Bluetooth) and the Software "Kubios HRV". The first measurement is after waking up at 8 o'clock in the morning at complete rest (see Figure 1). The second measurement was made after prolonged moderate walking $(12 \mathrm{~km})$ and consumption of 4 standard instant coffee cups (see Figure 2). The comparison shows that the stress-index is significantly higher after the combination of exercise and instant coffee. In our case you can compare the other parameters of (PRV) too $[3,4]$.

\begin{tabular}{|c|c|c|}
\hline \multicolumn{3}{|l|}{ RESTING HRV } \\
\hline Heart rate $59 \mathrm{bpm}$ & RMSSD $27 \mathrm{~ms}$ & \\
\hline \multicolumn{3}{|l|}{ PNS index 0.01} \\
\hline-5 & 0 & 5 \\
\hline \multicolumn{3}{|l|}{ SNS index $\mathbf{0 . 1}$} \\
\hline .5 & 0 & 5 \\
\hline \multicolumn{3}{|c|}{ HRV PARAMETERS } \\
\hline Mean RR & $1019.84 \mathrm{~ms}$ & \\
\hline SDNN & $33.22 \mathrm{~ms}$ & \\
\hline Pointcaré SD1 & $19.34 \mathrm{~ms}$ & \\
\hline Pointcaré SD2 & $42.95 \mathrm{~ms}$ & \\
\hline Stress index & 12.64 & \\
\hline
\end{tabular}

Figure 1: (After sleep in the morning). 


\section{(after long walking and 4 cups of instant coffee)}

\section{RESTING HRV}

Heart rate $61 \mathrm{bpm}$ RMSSD $17 \mathrm{~ms}$

PNS index $\mathbf{0 . 3}$

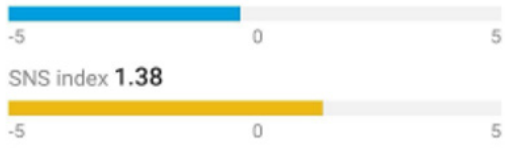

\section{HRV PARAMETERS}

$\begin{array}{ll}\text { Mean RR } & 991.73 \mathrm{~ms} \\ \text { SDNN } & 15.98 \mathrm{~ms} \\ \text { Pointcaré SD1 } & 11.97 \mathrm{~ms} \\ \text { Pointcaré SD2 } & 19.22 \mathrm{~ms} \\ \text { Stress index } & 20.83\end{array}$

MEASUREMENT QUALITY: GOOD

Figure 2: (After long walking and 4 cups of instant coffee).

\section{ISSN: 2574-1241}

DOI: $10.26717 /$ BJSTR.2021.36.005824

Ivan Domuschiev. Biomed J Sci \& Tech Res

This work is licensed under Creative Commons Attribution 4.0 License

Submission Link: https://biomedres.us/submit-manuscript.php

\section{Conflict of Interest}

The author declare that they have no conflict of interest.

\section{References}

1. Sarshin A, Naderi A, Da Cruz CJG, Foad Feizolahi, Scott C Forbes, et al. (2020) The effects of varying doses of caffeine on cardiac parasympathetic reactivation following an acute bout of anaerobic exercise in recreational athletes. J Int Soc Sports Nutr 17: 44

2. Southward K, Rutherfurd-Markwick KJ, Ali A (2018) Correction to: The Effect ofAcute Caffeine Ingestion on Endurance Performance: A Systematic Review and Meta-Analysis. Sports Med 48(10):2425-2441.

3. Corti R, Binggeli C, Sudano I, Spieker LE, Luscher TF, et al. (2000) Coffee leads to activation of the sympathetic nervous system. Eur Heart J21 (abstr): 105

4. De Oliveira RAM, Araújo LF, De Figueiredo RC, et al. (2017) Coffee Consumption and Heart Rate Variability: The Brazilian Longitudinal Study of Adult Health (ELSA-Brasil) Cohort Study. Nutrients 9(7): 741.

$\begin{array}{ll}\text { BIOMEDICAL } & \text { Assets of Publishing with us } \\ \text { RESEARCHES } & \text { - Global archiving of articles } \\ \text { - Immediate, unrestricted online access }\end{array}$

